Karol Łopatecki

Institute of History and Political Science

University of Białystok

\title{
Military Works of Albert of Hohenzollern. Comments on the Three Manuscripts Attributed to Albert of Hohenzollern in the Years 2009-2014*
}

Intensive archival and historical research conducted in the nineteenth and the twentieth centuries led researchers to think that all Renaissance military treatises were recognized and their content was subjected to a detailed analysis. ${ }^{1}$ For this reason we can perceive the identification in the years 2009-2014 of the three manuscripts written by Albert of Hohenzollern as a sensational discovery. This article is aimed to provide researchers with new sources together with their brief description and to discuss the current state of knowledge on the origins and the further fate of these manuscripts.

Albert of Hohenzollern is regarded as one of the most notable Renaissance authors writing about military matters. This opinion was based on the analysis of the only work known so far - written in 1555, entitled Kriegsordnung. The original was written in German

\footnotetext{
* Research funded by The Lanckoronski Foundation (agreement no. 41-2/11) and the National Science Centre (Poland), SONATA grant, agreement no. 2016/23/D/ HS3/03210.

${ }^{1}$ On the subject matter of works written during the Polish Republic of Nobles cf. i.a.: K. Olejnik, Rozwój polskiej myśli wojskowej do końca XVII wieku (Poznań, 1976); J. Sikorski, "Księgi hetmańskie Stanisława Sarnickiego na tle piśmiennictwa wojskowego w Polsce XVI wieku," pt. 1-2, Studia i Materiaty do Historii Wojskowości 12-13 (1966-1967).
} 
and six years later translated into Polish by Maciej Strubicz at the initiative of King Sigismund Augustus. While assessing the significance of the work researchers readily refer to the opinion of the outstanding nineteenth-century scholar studying these issues, Max Jähns, who decribed the Prussian Duke's treatise as the most outstanding work of the sixteenth century on military tactics. ${ }^{2}$ Contemporary researchers share this view. For instance Janina Nowakowa emphasises that while the first part of the treatise has a derivative character, the latter part, describing the cooperation of military units in the battle field, is original and a result of long study, deliberations and discussions. ${ }^{3}$ Nonetheless, the written in Königsberg work was not printed in the early modern period and it was not until 2006 that a critical source edition appeared. ${ }^{4}$

Kriegsordnung has been ever readily used by historians, not only those working on military topics. For instance Teresa Zarębska referred to the Polish version of the manuscript in a study on the development of urban planning, ${ }^{5}$ while Bogdan Burliga addressed the issue of the reception of ancient literature in the Prussian Duke's work. ${ }^{6}$ Studies on the treatise written by Hohenzollern commenced already in the nineteenth century were summarised in articles by Janina Nowakowa, published in $1985^{7}$ and by Matthias Rogg and Tadeusz Marian Nowak (placed as an introduction to the mentioned source

${ }^{2}$ M. Jähns, Geschichte der Kriegswissenschaften. Vornehmlich in Deutschland, pt. 1 (München and Leipzig, 1889), p. 524.

3 J. Nowakowa, "Księcia Albrechta Księgi o rycerskich rzeczach a sprawach wojennych w tłumaczeniu Macieja Strubicza z 1561 r.," Studia i Materiaty do Historii Wojskowości 28 (1985), p. 71.

${ }^{4}$ Die Kriegsordnung des Markgrafen zu Brandenburg Ansbach und Herzogs zu Preussen Albrecht des Älteren - Königsberg 1555, pt. 1-2, ed. H. J. Bömelburg, B. Chiari, M. Thomae (Braunschweig, 2006). Polish edition of the source, prepared by Janina Nowakowa ("Księcia Albrechta Księgi," p. 85) and Tadeusz M. Nowak in 1970, was not published until 2006 (ibidem, pp. 157-270). Cf. D. Pietrzkiewicz, "Rękopisy i stare druki w życiu i pracach profesora Tadeusza Mariana Nowaka," Studia i Materiaty do Historii Wojskowości 44 (2007), p. 45.

5 T. Zarębska, Początki polskiego piśmiennictwa urbanistycznego (Warszawa and Łódź, 1986), pp. 229-284 (Chapt. VI: "Koncepcje z pogranicza problematyki urbanistycznej w twórczości teoretyków wojskowości trzeciej ćwierci XVI wieku”).

${ }^{6}$ B. Burliga, "Ordunki versus arkebuzy dymiące. Tradycje i nowoczesność w Księgach o rycerskich rzeczach (Kriegsordnung) księcia Albrechta von Hohenzollerna,” in: Organizacja armii $w$ nowożytnej Europie. Struktura - urzędy - prawo - finanse, ed. K. Łopatecki (Zabrze, 2011), pp. 47-62.

7 Nowakowa, "Księcia Albrechta Księgi," pp. 71-87. 
publication). ${ }^{8}$ The subject matter concerning the origins of the first Prussian military treatise seemed to be already scrutinized. Published research results indicate that the Duke was committed to expanding his military knowledge. Thanks to the findings of Johannes Voigt, Janina Nowakowa and Kurt Forstreuter ${ }^{9}$ we know that he had a network of agents from whom he was receiving information. We are aware of how he acquired military publications, information about technological novelties, plans and scale models concerning fortifications as well as battle arrays and marching arrays and reports on warfare. He took into consideration opinions of authorities in the field of tactics and military. ${ }^{10}$

High regard enjoyed by Albert of Hohenzollern was based on his interests supported by his financial capability, and to a lesser extent on his actual achievements as a commander. He actively participated in military activities only several times: in 1509 he accompanied Maximilian I during the campaign to the Apennine Peninsula, in the years 1519-1521 he waged a lost war against the Kingdom of Poland, in 1525 he took part in the suppression of a peasant uprising in Sambia. ${ }^{11}$ Nonetheless, his contemporaries positively regarded his mili-

${ }^{8}$ M. Rogg, "Porządek wojenny Albrechta Hohenzollerna księcia Prus," in: Die Kriegsordnung, pp. 19-28 (German version: "Die Kriegsordnung Albrechts des Älteren von Brandenburg, Herzog in Preußen,” in: ibidem, pp. 137-146); T. M. Nowak, "Polska wersja Porządku wojennego Albrechta na tle stosunków polsko-pruskich," in: ibidem, pp. 29-38 (German version: "Die polnische Fassung der Kriegsordnung Albrechts vor dem Hintergrund der preußisch-polnischen Beziehungen," in: ibidem, pp. 147-156).

${ }^{9}$ K. Forstreuter, "Zu den Kriegsstudien des Herzogs Albrecht von Preußen," Altpreußische Forschungen 19 (1942), pp. 234-249; J. Voigt, "Des Herzogs Albrecht Kriegsstudien und Kriegsanstalten," Neue Preußische Provinzialblätter Ser. 3, 4, no. 1 (1859), pp. 1-55. See also P. G. Thielen, Die Kultur am Hofe Herzog Albrechts von Preussen (1525-1568) (Göttingen, 1953), p. $194 \mathrm{f}$.

10 Works by ancient and contemporary authors, used by Albert of Hohenzollern, listed in: Nowakowa, "Księcia Albrechta Księgi," pp. 86-87, and Nowak, "Polska wersja," pp. 151-152.

11 J. Małłek, Prusy Książęce a Prusy Królewskie w latach 1525-1548. Studium z dziejów polskiej polityki księcia Albrechta Hohenzollerna (Warszawa, 1976), pp. 31-35; idem, Ustawa o rządzie (Regimentsnottel) Prus Ksiązęcych z roku 1542. Studium $z$ dziejów przemian spotecznych i politycznych $w$ lennie pruskim (Toruń, 1967), p. 111; Rogg, "Porzadek wojenny Albrechta," pp. 137-138; S. Bodniak, "Albrecht Hohenzollern,” in: Polski Stownik Biograficzny, vol. 1 (Kraków, 1935), pp. 48-52; M. Biskup, "Wojna pruska", czyli wojna Polski z zakonem krzyżackim z lat 15191521. U źródet sekularyzacji Prus Krzyżackich (Olsztyn, 1991), passim; W. Szymaniak, Rola dworu polskiego w polityce zagranicznej Prus Książęcych. Studium 
tary skills, evidence of which was the intention of giving him command of an army of the Reich for a planned campaign against Turkey in the years 1541-1542. ${ }^{12}$ The military campaign of 1563 known as the "Nut War" was the culmination of the Duke's military career. The seventy-year-old Albert mounted a horse to lead an army composed of levy en masse from Ducal Prussia against Eric II, Duke of Brunswick-Lüneburg. During the campaign neither large battles were fought nor impressive military manoeuvres were carried out, while both sides limited themselves to hold their positions on the banks of the River Vistula to the north of Kwidzyn. Hohenzollern did not win a victory, instead the hardships of the campaign caused him to suffer a serious illness, which began on 22 September, resulting in partial paralysis, worsening over the years. ${ }^{13}$

Our knowledge concerning the Duke's intellectual work directly related to the writing of the military treatise seems rather modest in comparison to increasingly extensive knowledge about the military of Ducal Prussia. It is assumed that he started writing in the 1540s, "zapewne w związku z przygotowaniem się do roli dowódcy wojsk cesarskich w wojnie z Turkami”. ${ }^{14}$ I proposed a thesis in 2012, that the work was initially written as a peculiar type of corpus iuris militaris (the Duke intended just to copy his own and foreign normative acts, texts of oaths, information about soldiers' pay and military offices). ${ }^{15}$

Initially, the work had a private nature. Qualitative change occurred in 1552 when Sigismund II Augustus, the Duke's suzerain, stayed in Königsberg (12-14 September). ${ }^{16}$ The King's visit began unfortunately

z dziejów dyplomacji Prus Książęcych w Polsce w latach 1525-1548 (Bydgoszcz, 1993), pp. 51-53.

${ }^{12}$ Cf.: Nowak, "Polska wersja," p. 149; J. Wijaczka, Dziatalność dyplomatyczna Asverusa von Brandta $w$ latach 1538-1547 (Kielce, 1991), pp. 36-43; idem, Asverus von Brandt 1509-1559. Życie i dziatalność dyplomatyczna $w$ stużbie księcia Albrechta pruskiego (Kielce, 1996), pp. 56-66.

${ }^{13}$ Cf. M. Plewczyński, "Krzyżacy i prusacy książęcy w armii koronnej w latach 1497-1572," Zeszyt Naukowy Muzeum Wojska. Ośrodek Badań Historii Wojskowej 12 (1998), p. 44; R. Fischer, "Der Preußische Nußkrieg vom Jahre 1563," Altpreußische Monatsschrift 28 (1891-1892), pp. 38-75.

${ }^{14}$ Nowakowa, "Księcia Albrechta Księgi," p. 77.

${ }^{15}$ Cf.: K. Łopatecki, "Diciplina militaris" w wojskach Rzeczypospolitej do potowy XVII wieku (Białystok, 2012), pp. 36-37, 297, 484-485; Rogg, "Porzadek wojenny Albrechta," pp. 139-140, 143.

16 There exists an itinerary of the journey, entitled: "Droga Je[go] K[rólewskiej] Mosczi”, Российская национальная библиотека, Санкт-Петербург, Ф. 971, 
as one of the cannonballs fired in his honour hit young Prince Wiśniowiecki in the head, "aż na króla mózg wyskoczył". The Duke conducted an investigation, which revealed that the accident was caused by gunpowder scattered around under the cannon. The gunpowder caught fire and caused the change of position of the barrel. The gunner responsible for that was sentenced to death, but Sigismund Augustus protested, because "niesłusznie byłoby, aby puszkarz za niepostrzeżenie swoje miał być śmiercią karany". Eventually, the accused had to escape. ${ }^{17}$

It is possible that to compensate for the bad impression of the accident the Duke showed his collected materials concerning military matters to the King. As he mentioned, he was then close to abandon his study activity, but the last of the Jagiellons delighted with the work of his cousin, asked for its continuation, ${ }^{18}$ thereby making an unusual and honourable order. ${ }^{19}$ Giving someone a book on the subject

Авт. 321/1, № 3, fol. 6. In September 1552 Sigismund Augustus stayed in: Malbork (1-7), Elbląg (8), Frombork (9), Siekiercze (10), Brandenbork (11), Königsberg (12-14), Tapiewo (15), Taplaki (16), Jurzenbork (17), Kropiski (18), Ragneta (19-20), Swaba (21), Jurbork (22), Wielona (23), Wilika (24), Kaunas (25-26), Ziszmury [probably Żyżmory] (27), Siemieliszki (28), Troki (29), Vilnius (30). Cf. A. Gąsiorowski, "Itineraria dwu ostatnich Jagiellonów," Studia Historyczne 16, no. 2 (1973), p. 269.

${ }_{17}$ M. Murinius, Kronika mistrzów pruskich, ed. Z. Nowak (Olsztyn, 1989), pp. 239240; M. Bielski, Kronika, vol. 2, ed. K. J. Turowski (Sanok, 1856), pp. 1113 1114; Ł. Górnicki, Dzieje w koronie polskiey za Zygmunta I y Zygmunta Augusta $a \dot{z}$ do śmierci iego (Warszawa, 1754), pp. 49-51.

${ }^{18}$ Cf.: "A aczkolwiekem u siebie dobrze obaczył a prawie poznał złość ludzi świata teraźniejszego, jako źle a sprośnie o rzeczach też potrzebnych a pożytecznych niektórych mówią i źle je sądzą, iże za tą przyczyną słusznie bych był mógł tego przedsięwizięcia swego zaniechać a na stronę prawie odłożyć. Ale ponieważ się niedawnych czasów Najaśniejszy a Miłościwy Królu to przytrafiło, żem w onych społecznych rozmowach o takowych chwalebnych rzeczach nieco wspomniał przed Waszą Królewską Mością i na to mię po tym Wasza Królewska Mość przywieść a ku ukazowaniu tych rzeczy napomknąć raczył i nadto jeszcze po tym Wasza Królewska Mość miłościwie ode mnie tego żądać a chcieć raczył, abych ku czci a podobaniu Waszej Królewskiej Mości tej pracej nie litował, ale takowe rzeczy przed się wziął a Waszej Królewskiej Mość cząstkę niejaką tego, gruntownie spisaną, zebraną a sprawioną udzielił, wedle której by się Wasza Królewska Mość czasu wojenny potrzeby sprawować a rządzić i naprzeciwko nieprzyjacielowi postępować mógt," Albrecht Hohenzollern, "Księgi o rycerskich rzeczach, a sprawach wojennych z pilnością zebrane a porządkiem dobrem spisane," ed. T. M. Nowak, in: Die Kriegsordnung, p. 161.

${ }^{19}$ Albert of Hohenzollern already in the 1540s was sending prints to the royal court. Cf. A. Kawecka-Gryczowa, Biblioteka ostatniego Jagiellona. Pomnik kultury renesansowej (Wrocław, 1988), pp. 34-35. 
of military matters was at the time a great cultural event, an example of which was presenting Emperor Charles $V$ with a printed and handpainted work Kriegsmemorial written by Konrad von Bemelberg and Reinhard, Count of Solms. ${ }^{20}$ As a result of the arrangements made in Königsberg a military treatise in German was written, signed by the Duke on 10 August 1555, then presented to Sigismund Augustus. The decision to translate the book into Polish was probably taken after the nomination of Maciej Strubicz as the royal secretary for German affairs (21/04/1559). ${ }^{21}$ The task lasted over two years and ended before 1 August 1561 - the date is inscribed on the dedication written by Maciej Strubicz to Sigismund Augustus. ${ }^{22}$

The surviving manuscript of treatise (A) Kriegsordnung bin ich genant, Wer kriegt und ist in mir bekant, Der kan nach der zeit und gestalt, all sein schlachtordnung machen balt, Auch brauchen manchen vortheil gut, dem feindt zu stilln sein ubermut written by Albert of Hohenzollern was completed on 10 August 1555. Probably several copies were made - Sigismund II Augustus received one of them (missing), while the other was stored at the ducal library, ${ }^{23}$ the library of electors of Brandenburg in Berlin (at least until 1668), ${ }^{24}$ and currently is stored at Staatsbibliothek zu Berlin, in the collection Preußischer Kulturbesitz (catalogue number Ms. boruss. fol. 441). In addition to the dedication to the Polish King, ${ }^{25}$ surrounded by a cartouche with the White Eagle as a coat of arms and initials "SA", the manuscript includes an ex libris. The bookplate features seaside fortifications and military camps together with the coat of arms of the Brandenburg line

${ }^{20}$ Bayerische Staatsbibliothek München, MS 3363. Cf. J. A. Schmellers, Die deutschen Handschriften der K. Hof- und Staatsbibliothek zu Muenchen, vol. 2 (München, 1866), p. 383; R. Leng, Ars belli. Deutsche taktische und kriegstechnische Bilderhandschriften und Traktate im 15. und 16. Jahrhundert, vol. 2 (Wiesbaden, 2002), pp. 221-222.

21 T. Kempa, "Strubicz Marcin," in: Polski Stownik Biograficzny, vol. 44, fasc. 3 (182) (Warszawa and Kraków, 2006-2007), pp. 425-428.

22 Czartoryski Library (Biblioteka Czartoryskich [hereafter: BC]), MS 1813, fol. 5; Nowakowa, "Księcia Albrechta Księgi," pp. 78-79.

${ }^{23}$ Kawecka-Gryczowa, Biblioteka, p. 299, poz. 3.

${ }^{24}$ G. C. Pisanski, Entwurf einer preussischen Literärgeschichte in vier Büchern, ed. R. Philippi (Königsberg, 1886), pp. 108-109; F. Bentkowski, Historia literatury polskiej, vol. 2 (Warszawa, 1814), pp. 356-358.

25 "ME BELLI VOLVCREM VIRTVS GENEROSA CREAVIT, LAETA QUOD INTEREPIDOS HORTORADARMA DVCES. HINC OPERI FAVEOTIBI REX AVGVSTE DICATO, ILLVUS, SI QVANDO SVMPSERIS ARMA, COLE”. 
of the Hohenzollern dynasty and the handwritten signature Georgius Albertus Marchio Brandenburgensis. ${ }^{26}$ The treatise consists of the Prolegomenon with the aforementioned dedication, a rhymed preface ${ }^{27}$ and a table of contents. The text of the treatise may be divided into two parts. In the first one - conventional and similar to other contemporary military studies - the author gathered together articles of war, ordinances, texts of oaths and presented information about military officials (fols. 1-84). All of this was grouped into seven main topics: siege warfare, the role of the artillery, the knowledge of systems of measurement, the description of infantry and cavalry and maintaining the order of march (military wagon convoys, military camps, battle preparations, provisioning). ${ }^{28}$ There are interesting calculation tables related to soldiers' pay, supplying and the surface area taken up by soldiers set in array. The second part is innovative in nature and constitutes the contribution of Albert of Hohenzollern to the development of the Renaissance art of war (fols. 85-213). ${ }^{29}$ The Duke depicts 42 battle arrays, then describes the possibilities of realigning units on the battlefield, which is complemented with eleven geometric models. In the latter part of the text the Duke describes military wagon convoys and different types of military camps. The book ends

26 The copy was the property of Georg Albrecht, Margrave of Brandenburg-Bayreuth-Kulmbach (1619-1666). Cf. Thielen, Die Kultur, p. 195; K. Hoburg, "Kriegsordnung von Herzoge Albrecht von Preußen," Neue Preussische ProvinzialBlätter 5 (1860), pp. 171-172.

27 The poem is identical with the piece Lere, so Kayser Maximilian in sejner ersten jugen gemacht vnnd durch eyn trefflichen erarn man sejner kriegsräth jm zugestllt ist. Cf. Jähns, Geschichte der Kriegswissenschaften, pp. 333-339, 518.

${ }^{28}$ Cf. Burliga, "Ordunki," pp. 52-53.

${ }^{29}$ It is worth emphasising that the novel approach was noticed by the contemporaries. Strubicz wrote in the foreword: "ty to księgi około wojennych rzeczy, a postępków z pilnością spisał i z innych rozmaitych autorów, co też z dawna o tym wiele pisali, co naprzedniejsze a potrzebniejsze nauki wybrał, też $\mathrm{k}$ temu zdanie swoje wedle nalepszej wiadomości swej około każdy rzeczy opisał, a wedle potrzeby przyłożył, że ich słusznie mogę zwać naprzedniejszymi a naczelniejszymi księgami w rzeczach rycerskich napisanych, acz ci tu żadnych nie ganię, bo każdy wedle nalepszego porozumienia a zdania swego onych czasów o tychże rzeczach pisał, ale mi się nie zda, żeby u każdego autoro to mogło być naleziono, żeby tak wielka pilność miała być zachowana, tak w pisaniu rzeczy samej, jako i w malowaniu i ukazowaniu rozmaitych figur około szyków rozlicznych, też około porządnech obozów położenia wojska, a czynienia legrów i innych rzeczy potrzebych", BC, MS 1813, p. X; Albrecht Hohenzollern, "Księgi o rycerskich rzeczach," p. 157. 
with a short essay entitled Bericht des turkischen keiser schlachtordnung (fols. 209-213). ${ }^{30}$

The original of the translated version (B), entitled Ksiegi o rycerskich rzeczach a sprawach wojennych, z pilnościa zebrane a porzadkiem dobrem spisane, is stored at the Princes Czartoryski Library in Kraków (MS 1813). ${ }^{31}$ The translation is slightly longer than the original and it consists of 82 pages of the introduction (numbered with Roman numerals) and 597 pages of the treatise (numbered in Arabic numerals). There are only a few new parts written by Maciej Strubicz. The foreword by the translator, in which the Duke's effort and the role of Sigismund II Augustus are praised, should be noted in the first place. The text entitled Do czytelnika mitego is also new. ${ }^{32}$ Furthermore, the title of the work (A) was translated ${ }^{33}$ and a portrait of Albert of Hohenzollern was added, which is adorned with the Latin inscription above ("Vera effigies illustrissimi principis et domini, domini Alberti, dei gratia senioris marchionis brandenburgensis et in Prussia ducis, sterinensis, pomeranensis, Cassuborum Sclavorumque principis, burgrabii norembergensis Rugiaeque ducis etc., anno aetatis suae 72 ”), ${ }^{34}$ and the Polish inscription below ("Ten obraz od żywego mało się tu umyka, ale nikt nie wyrazi, co się cnót w nim zamyka”). The portrait

${ }^{30}$ Evidently, this part had its genesis in Albert's preparations to be in command during a war against the Turks. Already in 1542 he received information about the Turkish army from an imperial diplomat Sigismund von Herberstein and two years later - a detailed plan of Turkish arrays from Jan Tarnowski. Cf. J. Voigt, "Herberstein mit dem Herzog Albrecht von Preussen," Archiv für Kunde österreichischer Geschichts-Quellen 17 (1857), p. 284; Nowak, "Polska wersja," p. 149.

31 On the basis of this manuscript Kajetan Kielesiński (a librarian working with the Kórnik collection since 1839) made a copy stored at the Kórnik Library of the Polish Academy of Sciences (MS 669). It is a book, the size of which is $28 \mathrm{x} 41 \mathrm{~cm}$, consisting of 252 folios. An introduction to this manuscript, entitled Alberti Marchionis Brandenburgensis, ducis Prussiae Libri de arte militari was published in Paris in 1858.

32 BC, MS 1813, pp. XIII-XIV; Albrecht Hohenzollern, "Księgi o rycerskich rzeczach,” pp. 159-160. The part was ascribed to Albert of Hohenzollern and passages from it were quoted as the Duke's words, Nowakowa, "Księcia Albrechta Ksiegi," pp. 78, 86; Burliga, “Ordunki," pp. 55f.

33 "Ordunkiem wojennym jesteśmy przezwane, / Od wojującego, gdy będziemy poznane, / Kto nas wyrozumie, wnet czasu każdego / Nauczy się szyku ku bitwie prędkiego, / K temu używając fortelu dobrego / Może skrócić wolą przeciwnika swego", BC, MS 1813, p. XVII.

34 The signature at the base of the portrait of the Duke indicates that it was done in 1562 , which shows that the portrait was later than the translation. 
still existed in 1818, when Łukasz Gołębiowski described the manuscript, although already in 1852 Wacław Aleksander Maciejowski recorded that the drawing had been removed. ${ }^{35}$ The latter part of the introduction is a faithful translation of the manuscript of 1555.

Historians undertaking the analysis of the original and the translation were focused on the possibility of the existence of more copies and examined the circumstances of the writing and the fate of individual copies. ${ }^{36}$ However, they did not bring to light at least two critical questions. Firstly, did any other military treatise written in the late 1540 s or early 1550 s exist? Albert of Hohenzollern must have been in 1552 the author of one work, which he showed to Sigismund II Augustus. He writes about it directly in the foreword to Sigismund II Augustus: "nalazłem i obaczyłem to, iże w onym egzemplarzu, com go Waszej Królewskiej Mości pierwej pokornie ukazował, wiele przyczyniać i jaśniej wypisać było potrzeba". ${ }^{37}$ The Duke did not perform only editorial tasks but created a new work, which took him three years. He did not work alone due to a multitude of duties, so he had to "osób inszych w tych rzeczach biegłych, które się około miar i rzeczy inszych rycerskich ku temu potrzebnych dobrze rozumieją do siebie wezwać a pomocy ich w tym używać". ${ }^{38}$

Secondly, it was assumed a priori, that Albert of Hohenzollern abandoned studying military theories in 1555 . The psychological aspect was omitted - the Duke had a passion for writing military scientific works. A great reception of the book at the royal court may

35 Cf. Nowakowa, "Księcia Albrechta Księgi," p. 82; W. A. Maciejowski, Piśmiennictwo polskie od czasów najdawniejszych aż do roku 1830, vol. 3 (Warszawa, 1852), p. 242.

${ }^{36}$ It was emphasised for instance, that at the beginning of the twentieth century existed two Polish versions of the treatise (B), stored in Krakow and Saint Petersburg. On the missing Saint Petersburg book there were annotations indicating that in the seventeenth century the book belonged to Jan Karol Chodkiewicz and in the eighteenth century - to Jakub Sobieski and Andrzej Stanisław Załuski. Probably, the work used to belong also to Jan or Grzegorz Chodkiewicz and John III Sobieski. The other copy was the property of Polish monarchs, robbed by the Swedes in 1655. Cf. J. Korzeniowski, Zapiski z rękopisów Cesarskiej Biblioteki Publicznej w Petersburgu i innych bibliotek petersburskich. Sprawozdanie z podróży naukowych odbytych w 1891-1892 i 1907 r. (Kraków, 1901), pp. 261-262; Nowak, "Polska wersja," pp. 153-154.

37 Unless otherwise stated, all the underlines and comments in the cited texts come from the author of the article.

${ }^{38}$ Cf. BC, MS 1813, p. XXIV; Albrecht Hohenzollern, "Księgi o rycerskich rzeczach,” p. 162. 
have motivated him to further work. Undoubtedly, with Sigismund II Augustus' consent Maciej Strubicz composed a panegyric, placed in the part entitled Do czytelnika mitego and acknowledged Hohenzollern as the most eminent, contemporary military theoretician, placing him among ancient authors: Aelianus Tacticus, Thucydides, Xenophon, Epaminondas, Herodotus, Plutarch, Arrian. He also emphasised the Duke's royal connections, calling him a member of "tego najaśniejszego, sławnego a prawie świętego narodu królów polskich". Moreover, as already mentioned, the portrait of the Duke appears before the text of the treatise, while it is not an element of the German original. ${ }^{39}$ These amplifications may be regarded as a kind of payment or recognition for efforts put into creative work, encouraging to undertake other analogous projects. ${ }^{40}$

In 2009 the information spread around the scientific world that a private collector put a beautifully illuminated Renaissance manuscript up for auction at Sotheby's Auction House in London (version $\mathrm{C})^{41}$ Due to the considerable value of the work it was decided to conduct a detailed research aimed to establish the authorship and the time of writing. ${ }^{42}$ The manuscript was made available to Pamela Porter, who had been studying another treatise stored at the British Library (version D) ${ }^{43}$ and had also known the source edition of

${ }^{39}$ It is possible that the idea to place an equestrian portrait of the Duke was taken from the work Kriegsmemorial given to Charles V in 1545, in which an analogous portrait was placed on fol. 3 .

40 The praise for Albert of Hohenzollern's work was accepted by intellectual elites as evidenced by the fact that Stanisław Sarnicki while writing Ksiegi hetmańskie ranked the Duke's work among the seven most important treatises written by "Polish Lords", The Central Archives of Historical Records, the Potocki Family Public Archive, catalogue number 325, vol. 1, p. 5.

41 The seller who put the work up for auction at Sotheby's Auction House remained anonymous. The only certain information was that he or she was not the first owner and inherited the manuscript.

42 Eventually, the work valued at 70,000-100,000 British pounds reached the price of 289,250 pounds at the auction (7 July 2009). See http://www.sothebys.com/ en/auctions/ecatalogue/2009/western-manuscripts-and-miniatures-and-the-korner-sale-109740/lot.25.html (accessed: 12/08/2011).

${ }^{43}$ Harley MS 1413. Pamela Porter began working in 1969 in the Department of Manuscripts at the British Museum, presently the British Library, where from the very beginning she occupied herself with the Harley Collection. The collection, which consists of more than 7500 copies was transferred to the British Museum in 1753. Cf. P. Porter, "Bindings from the Baltic - the Curator and Conservation," in: Care and Conservation of Manuscripts 5. Proceedings of the 
Kriegsordnung together with the facsimile (version A) of 2006. Her research activity yielded excellent results as she managed to identify two manuscripts as one, previously unknown to science, a book written by Albert of Hohenzollern. ${ }^{44}$

The problem with the identification of the volume, stored at the British Library (D) was that it was deprived of the title and the information about the author. It was a text divided into four books numbered from VII to $\mathrm{X},{ }^{45}$ therefore it was speculated that it may be the second or the third part of some unknown work. ${ }^{46}$ Meanwhile, the situation explained when a manuscript consisting of books numbered from I to VI was put up for auction. Both parts were perfectly matched with each other as far as their contents were concerned as well as in a technical respect.

Admittedly, the author of the completed work $(\mathrm{C}+\mathrm{D})$ did not sign his name either on the title page or in the introduction or placed it on the colophon. However, Albert of Hohenzollern's authorship is beyond doubt. ${ }^{47}$ The title of the book, the same as of the earlier work of the Prussian Duke is the evidence in support of this assumption (see fig. 1). ${ }^{48}$

fifth international seminar held at the University of Copenhagen 19th-20th April 1999, ed. G. Fellows-Jensen, P. Springborg (Copenhagen, 2000), pp. 88-89.

44 "Fortunately it was possible to make a very brief examination of this volume before the sale took place, providing conclusive confirmation that it is indeed the missing first half of Harl. MS. 1413. The volumes are of a comparable size, both texts are written in the same backward-sloping hand with the same form of calligraphic headings and flourishings, and their illustrations match perfectly in format, style and - in the case of individual watercolour drawings - dimensions. In addition a water-mark was noted matching that occurring throughout the Harleian manuscript, namely a heraldic shield as described above, which appears to be identical with a water-mark associated with Königsberg in 1553," P. Porter, "A Fresh Look at Harley MS. 1413. A Book ... fairly written in the German or Switz language," The Electronic British Library Journal 8 (2009), p. 10.

${ }^{45}$ A Catalogue of the Harleian Manuscripts in the British Museum, vol. 2: No. 1301-3099 (London, 1808), pp. 36-37.

46 Still in 2000. Porter, "Bindings," p. 89, was of the opinion that it was the third part of the work. Cf. A Catalogue of the Harleian Manuscripts, p. 36.

${ }^{47}$ It is worth emphasising that the authorship of the first part of the work (C) was established by the antiquarian firm Bernard Quaritch already in 1908 and the information spread around the scientific world. Cf. Description of an Important Manuscript on Military Science Written for Albert of Brandenburg, 1st Duke of Prussia: in the Possession of Bernard Quaritch (London, 1908), pp. 1-3.

48 "Kriegsordenung bin ich genant, Wer kriegt und ist in mir bekant, Der kan nach der zeit und gestalt, / All sein schlachtordnung machen balt. Auch brauchen manchen vortheil gut, Dem feindt zu stilln sein ubermut”. 

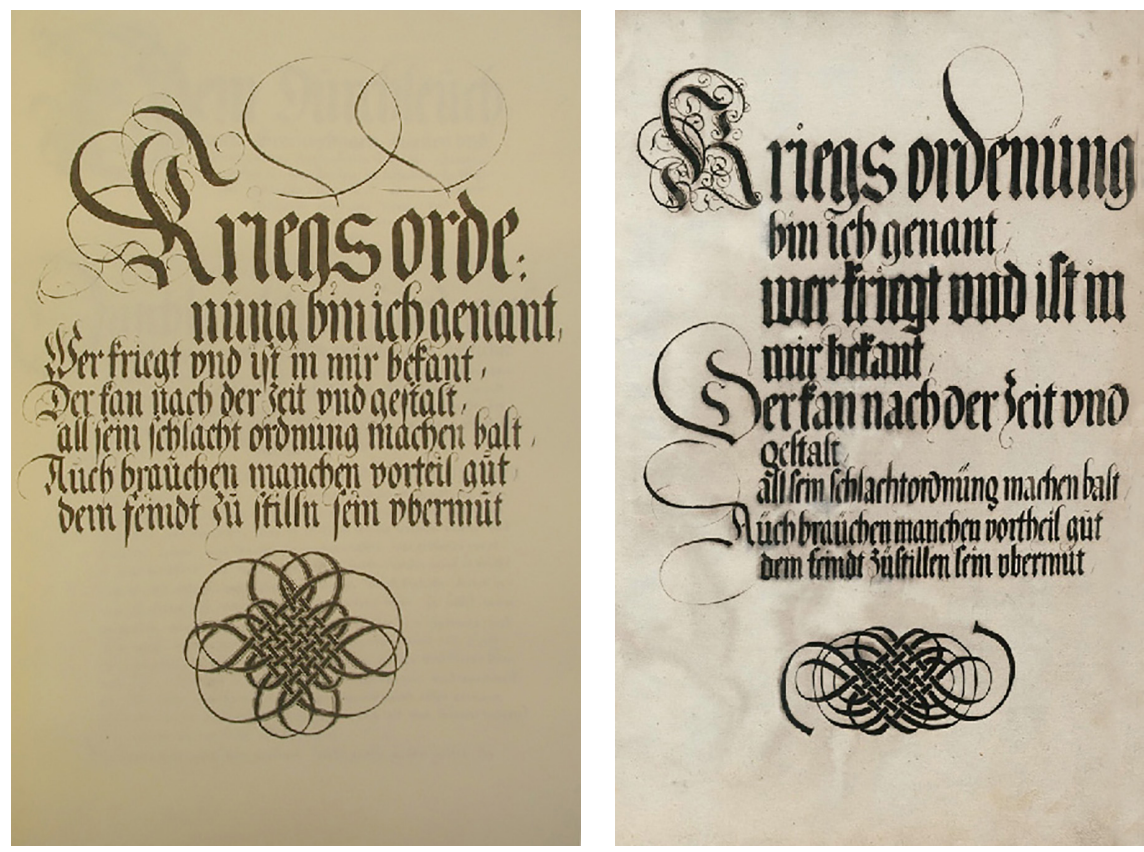

Fig. 1. Title pages of Albert of Hohenzollern's works (MSS A and C)

It should immediately be emphasised that, even though there are similarities between vast fragments of the texts, differences prevail and the wealth of information provided is much more impressive than that provided in versions A and B. The book put up at auction, which is worth mentioning, contained Albert of Hohenzollern's heraldic shield featured on the folio following the title page (for comparison purposes I present the miniature and a woodcut from Lexicon by Jan Mączyński, Königsberg 1564; see fig. 2). ${ }^{49}$ On the next page there was a portrait. It depicts the Prussian Duke in a full suit of armour (without a helmet) riding a horse, surrounded by three guards (see fig. 3).$^{50} \mathrm{I}$ think that the work B, in which Maciej Strubicz with Sigismund Augustus' approval applied such an idea, was

49 J. Mączyński, Lexicon Latino Polonicum ex optimis latinae lingvae scriptoribus concinnatvm (Królewiec, 1564), p. [13]. Cf. J. Tondel, Srebrna Biblioteka księcia Albrechta Pruskiego i jego żony Anny Marii (Warszawa, 1994), p. 84.

50 Persons analysing the treatise $C$ believe that that illustration on the page 54 shows the Prussian Duke. Cf. E. Ovegaauw, "Die Kriegsordnung des Markgrafen Albrecht von Brandenburg-Ansbach. Eine Neuerwerbung der Staatsbibliothek zu Berlin,” Bibliotheks Magazin 3 (2011), p. 63. 

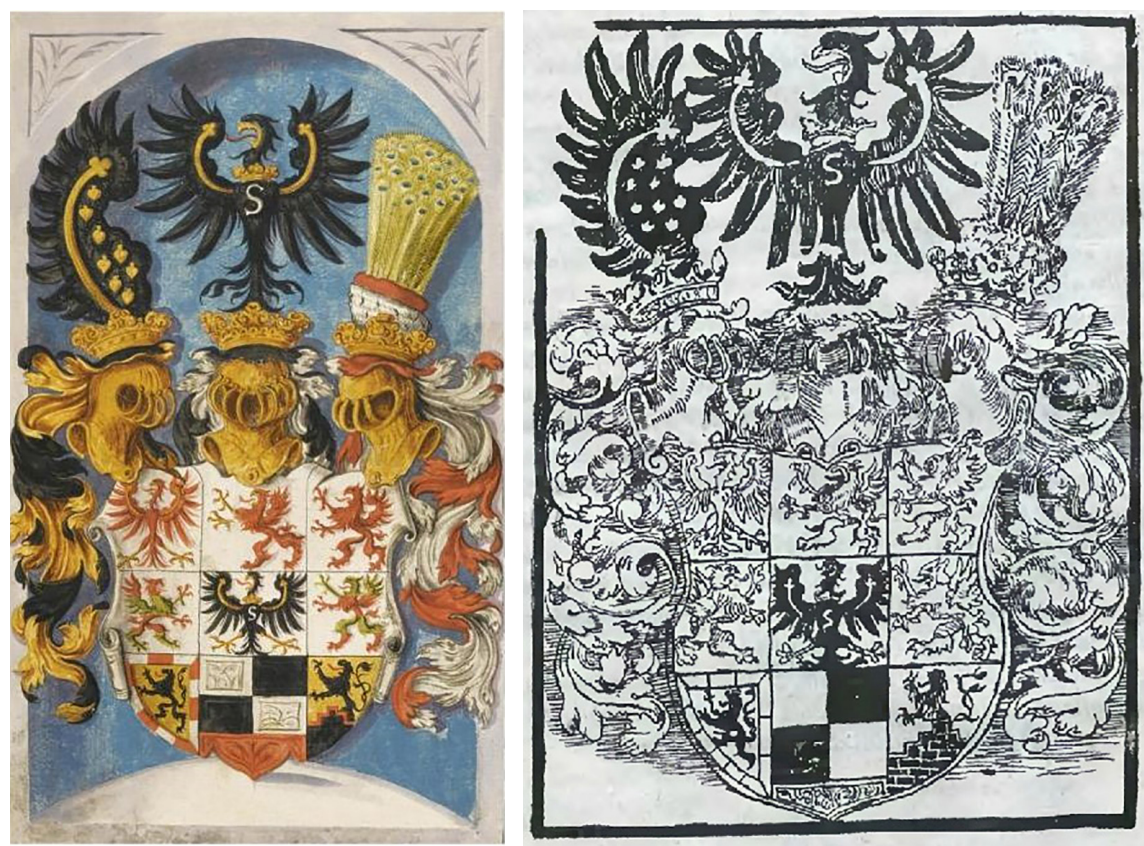

Fig. 2. Albert of Hohenzollern's heraldic shield

a source of inspiration here. ${ }^{51}$ The illustrations that appear in the text (in particular those contained in the second part of the work - D for instance plans of military camps and 42 battle arrays) were identical or very similar to those contained in the Berlin version (A) and the Krakow version (B). ${ }^{52}$

It was a prerequisite for the possibility of putting the work at auction to eliminate the risk that the manuscript was stolen during the Second World War. The task turned out to be uncomplicated, because in 1908 the antiquarian firm Bernard Quaritch printed a four-page brochure entitled Description of an Important Manuscript on Military Science Written for Albert of Brandenburg, 1st Duke of Prussia: in the Possession of Bernard Quaritch. It dispelled doubts over the origin of

${ }^{51}$ It is worth emphasising that the image of the Duke can be extremely rarely found in the Königsberg collection. There existed a woodcut portrait (by Lucas Cranach the Younger) and portraits placed on medallions adorning bindings stored in the silver library. Cf. Tondel, Srebrna Biblioteka, pp. 14, 36, 90, 122.

52 For instance the depiction of the military camp in the Harley manuscript, MS 1413 (fol. 18ver.-19) is the same as the first of the three military camps featured in the Berlin manuscript - Staatsbibliothek zu Berlin, Preußischer Kulturbesitz, Ms. boruss. fol. 441, fol. 203ver.-204. 


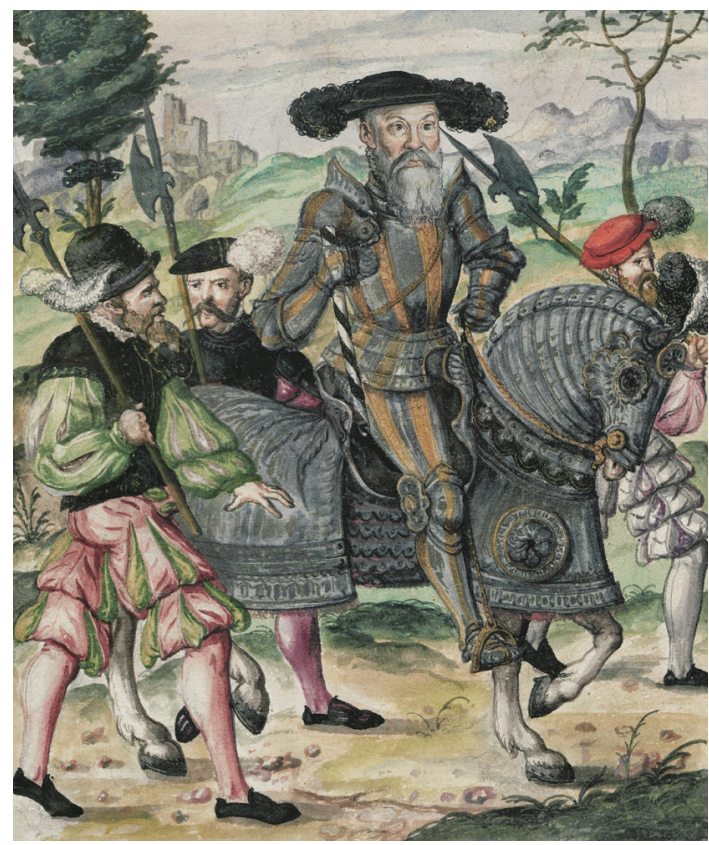

Fig. 3. Portrait of Albert of Hohenzollern (MS C)

the manuscript auctioned at Sotheby's in $1908 .{ }^{53}$ An anonymous person came into possession of the work at the time and the manuscript was not made available to anyone for scientific purposes. Pamela Porter deduced that the two volumes of the work must have been carried to Great Britain at the same time. However, soon afterwards they were separated. It is almost certain that the owner of both parts (C and D) was John Spicer. ${ }^{54}$ Following his death in 1710, the executor of his estate Foresitht sold the book collection (containing the volume D) and recorded that the collection included a beautifully crafted book (Spicer had this book in a country house before his death).

It is difficult to establish the circumstances and time of writing of the work. As it was pointed out in the catalogue of 1908 Albert

53 Porter, "A Fresh Look," pp. 9-10.

54 There are not any precise clues as to the way John Spicer came into possession of the work. Porter, "A Fresh Look," p. 8, supposes, that he might have purchased it together with the collection which used to belong to the late John Saunders, who had bought the books from John Withie (d. ca. 1678) after he became the owner of Edward Barwick's book collection. (d. 1650). The man might have bought the manuscript through his brother John Barwick, the dean of St. Paul's Cathedral in London. 
of Hohenzollern's advanced age (see fig. 3) indicates the 1560 s. ${ }^{55}$ However, Pamela Porter thinks that the work was written at the same time as the Berlin version (A). According to the researcher after 1552 the Prussian Duke wrote one treatise for Sigismund II Augustus and the other, dedicated to European military commanders. The proof is in the introduction to the part $\mathrm{C}$, in which there are addressees of the dedication: princes, generals, captains, lieutenants, all the officers of the regiment. ${ }^{56}$ However, it was not sent, but it passed to the library of the Dukes of Prussia in Königsberg. This is evidenced by the original binding ( $\mathrm{D}$ - replaced in 1968), which seems to be a work by Hans Guttich, working in Königsberg circa $1575 .{ }^{57}$ Another proof of the Königsberg provenance may be the filigree watermark (C), very similar (but not identical) to watermarks created on handmade paper in Königsberg in 1553 (see fig. 4). ${ }^{58}$
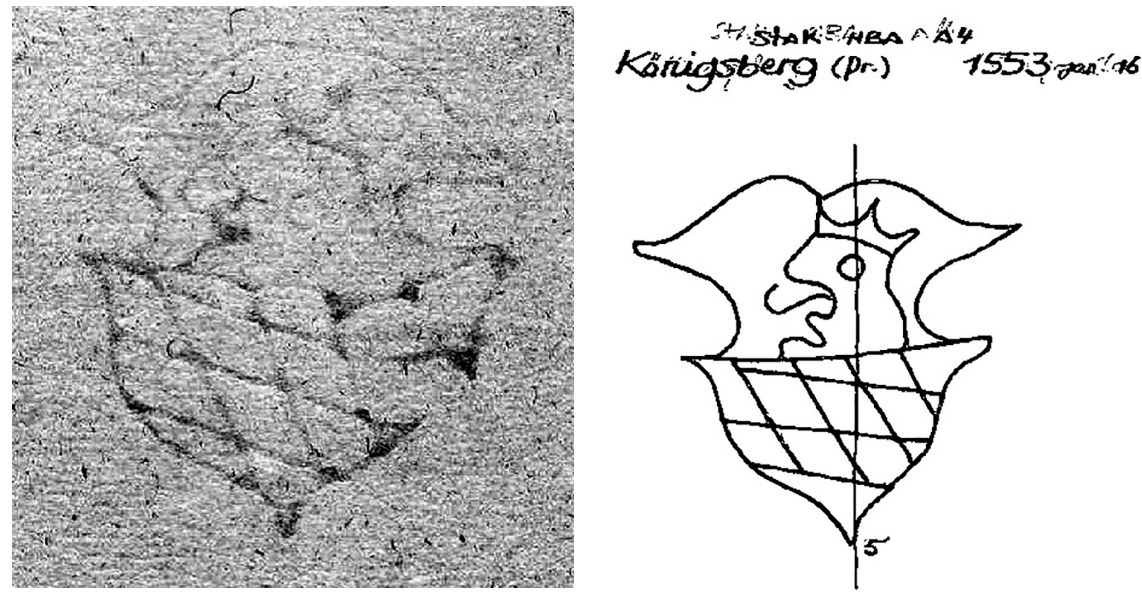

Fig. 4. Filigree watermark on the leaf of the treatise $\mathrm{C}$ containing the watermark of the Königsberg paper mill

While agreeing with the majority of the above observations, my view is that the writing of the work $\mathrm{C}+\mathrm{D}$ was not completed until Albert of Hohenzollern's death (1568). The manuscript C constitutes a coherent whole as opposed to the manuscript D. The last book (X)

55 Cf. Description of an Important Manuscript, pp. 1-2.

${ }^{56}$ Cf. Staatsbibliothek zu Berlin, Ms. boruss. fol. 1254, p. 7.

57 Cf.: Porter, “A Fresh Look," p. 11; eadem, "Bindings," pp. 88-92.

58 Porter, "A Fresh Look," p. 10, equates the filigree watermark on the leaves of the treatise to the watermark dated to 1553; see http://www.piccard-online.de. 
concerns military activities at sea, which Albert of Hohenzollern never wrote about before. Then fourteen coloured illustrations were inserted: two of them show sieges and are related to Book IX, while the remaining ones depict military inventions, so they should be linked with yet another part, which the Prussian Duke did not write. ${ }^{59}$

The argument in favour of dating the work to 1560 s seems to be the placing of the image of Albert of Hohenzollern at the beginning of the book (C) as it was the case with the Polish translation of 1561 (B). It is a very interesting hypothesis according to which the drawing (fig. 3) shows the seventy-year-old Duke at the head of the levy en masse during the "Nut War" of $1563 .{ }^{60}$ Furthermore, the structure of the work clearly suggests that we are dealing with a successive stage of the Duke's scientific work. Albert of Hohenzollern's willingness to advance the knowledge of the subject matter is reflected by the colophon located both in the treatise A and the treatise B: "Aczkolwiek by jeszcze siła potrzebnych a pożytecznych rzeczy ku tym sprawam a postępkom możono wynajdować, wymyślać a tu wypisować, ale że to wszytko więc wedle postępku a sposobu rzeczy i wedle czasu też bywa zrządzono a postanowiono, przeto ku rozsądku a obaczeniu i wyrozumieniu każdego rycerskiego pana [- $[-]$ postępowali, a dla krótkości tegom tu na ten czas szyrszemi słowy dalej wypisać poniechał". ${ }^{61}$

In contradiction to what Maciej Strubicz emphasised, the Duke had yet a lot to say. The brief form of the book resulted from a lack of time. The Duke also writes about it in the introduction, emphasising: "Waszej Królewskiej Mość cząstkę niejaką tego, gruntownie spisaną, zebraną a sprawioną udzielił, wedle której by się Wasza Królewska Mość czasu wojenny potrzeby sprawować a rządzić i naprzeciwko nieprzyjacielowi postępować mógł". ${ }^{62}$

${ }^{59}$ Cf. British Library, MS Harley 1413, fol. 212-224.

${ }^{60}$ Cf. Fischer, "Der Preußische Nußkrieg," pp. 38-75; Plewczyński, "Krzyżacy," p. 44. It is known, that at the age of 58, in a full suit of armour he went to Krakow at the head of his retinue to attend Sigismund I the Old's funeral. Sarnicki mentions: "Nieboszczyka też książęcia pruskiego chwała jako w swej starości we zbroi z Prus aże do Krakowa na pogrzeb Zygmuntów jeździł, alie był prawi, viridi senecta et habuit robur militare jako o niem Niemcy piszą", The Central Archives of Historical Records, the Potocki Family Public Archive, catalogue number 325, vol. 1, p. 81.

${ }^{61}$ BC, MS 1813, p. 298; Albrecht Hohenzollern, "Księgi o rycerskich rzeczach,” p. 270. German version: Staatsbibliothek zu Berlin, Preußischer Kulturbesitz, Ms. boruss. fol. 441, fol. 213.

62 Albrecht Hohenzollern, "Księgi o rycerskich rzeczach,” p. 161. 
Indeed, the last fragment concerning the Turkish military in the treatises $\mathrm{A}$ and $\mathrm{B}$ is disconnected from the whole and seems to be uncompleted. The treatise $\mathrm{C}$ begins with the military capability of the Ottoman Porte, so in some ways it complements the earlier compendium. The author writes in the following order about: views on the essence of war, the necessity of taking military action by the Christian world against the Turks, the Turkish army (for instance he compares it to European armies). ${ }^{63}$ The commencement of work on the in-depth study on the military of the Ottoman Empire might have been connected to the sending by captain Kasper Schellenschmidt (Achilles Scypion Nolan) to Albert of Hohenzollern a two-part treatise on the art of war, in particular the Turkish. ${ }^{64}$ The parcel was not delivered to the Duke. The ruler of Prussia received it in the following year and this time the treatise was bound in one volume. ${ }^{65}$

I think that the words of the introduction to the treatise $\mathrm{B}$, in which the Prussian Duke was recognised as the most outstanding military theoretician, prompted Albert to share his knowledge with other rulers and European commanders, because achieving fame of a victorious commander was his unrealized dream. Maciej Strubicz when commenting about the book as if from the author's perspective expresses a view that the work constitutes "pamiątkę maluśką po sobie, aby z niego poznano jakiego umysłu a serca [- - ] był. Że jednak ponieważ k temu nigdy przyjść nie mógł, aby sobie w rzeczach rycerskich naprzeciwko nieprzyjacielowi Waszej Królewskiej Mości ręką pamiątkę jaką uczynić mógł, tym jedno sobie pamiątkę maluśką uczynił a zostawił”. ${ }^{66}$

${ }^{63}$ Staatsbibliothek zu Berlin, Preußischer Kulturbesitz, Ms. boruss. fol. 1254, pp. 1-53.

${ }^{64}$ Schellenschmidt was the author of two works: Instruction und Ordnung der Kriegsrüstung - written in 1553 and Türckensteuer, - written four years later, which was delivered to Albert. Cf. M. Jähns, Geschichte der Wissenschaften in Deutschland, vol. 21: Altertum, Mittelalter, XV. und XVI. Jahrhundert (München and Leipzig, 1889), pp. XXXVI, 529-533; A. Lubos, Geschichte der Literatur Schlesiens, vol. 1, pt. 1: Von den Anfängen bis ca. 1800 (Würzburg, 1995), p. 112; O. Günther, Katalog der Danziger Stadtbibliothek, vol. 2: Katalog der Handschriften, pt. 2 (Danzig, 1903), pp. 236-237.

${ }^{65}$ K. Forstreuter, Beiträge zur preußischen Geschichte im 15. und 16. Jahrhundert (Heidelberg, 1960), p. 65; J. Wijaczka, Asverus von Brandt, p. 57; Thielen, Die Kultur, pp. 221, 228.

${ }^{66}$ Albrecht Hohenzollern, "Księgi o rycerskich rzeczach," p. 158. Joint military action of the King and the vassal took place during the Pozvol campaign of 1557. However also at the time diplomatic action led to the end of the war. 
The treatise $\mathrm{C}+\mathrm{D}$ as compared to the treatises $\mathrm{A}$ and $\mathrm{B}$ constitutes a display of great erudition, military knowledge and testifies to the fact that a huge collection of materials on the subject of military matters was assembled. ${ }^{67}$ A detailed elaboration of the content of the manuscript deserves a separate monograph, therefore at this point I will confine myself to several comments. Firstly, Book V constitutes a peculiar type of corpus iuris militaris - a compendium of normative acts. In the vast majority of cases they are related to the states of the Reich of the first half of the sixteenth century (the oldest dated document bears the date of 4 June 1552). What may surprise us, however, is that the book has a Pan-European spectrum. There can be found articles of war from France, Denmark, Sweden and Poland. The most spectacular is the knowledge of English statutes of war drawn up during the reign of Henry VIII, which were translated into German. ${ }^{68}$ Furthermore, the Duke placed an appendix at the end of the treatise C, entitled Von der Kriegshandlüng, in which he depicts the history of ancient Rome and the Byzantine Empire (Octavian Augustus - p. 444, Philip the Arab - p. 747, Constantine I - p. 749, Leo I - p. 752, Anastasius I - p. 755).

Information about the rules of recruitment in the Polish army is interesting - especially out of regard for Polish affairs. ${ }^{69}$ Including the information is related to the recruitment by Albert of Hohenzollern in 1556 of Polish cavalry units under Bernard Pretwicz's command. Already one year earlier, operating in Ruthenia and Lesser Poland the starost of Trembowla made for the Duke a list of potential rotamasters, who expressed their interest in the service for 6 Polish ztotys per month. Eventually, in July 1556 Hohenzollern decided to recruit 400 hussars and 400 cossack cavalrymen. However, rotamasters made several conditions: raising the pay to 7 Polish ztotys, issuing letters guaranteeing compensation for material damages (Polish: "listy zaszkodne"), obtaining from the King letters permitting the march of troops across the Polish Crown, issuing enrollment letters with a signature and a seal, which should include information about

${ }^{67}$ For instance in 1535 the Duke imported from Nuremberg movable models of then invented lever devices for raising cannons. The invention was described on the pp. 273-274 of the treatise, Staatsbibliothek zu Berlin, Ms. boruss. fol. 1254. Cf. Voigt, "Des Herzogs Albrecht," pp. 39-40.

68 Staatsbibliothek zu Berlin, Ms. boruss. fol. 1254, pp. 153-154, 513, 533-543, 544-582, 583-589, 605-616.

${ }^{69}$ Ibidem, pp. 153-154. 
at least a five-month period of service. The contract with the rotamasters was to be concluded at the moment of "taking the money". After having received rotamaster's articles (bestallung) and at least two months' pay rotamasters also demanded that "na myesczu bily popysany: kogo W.X.M. raczi przisslacz $\mathrm{k}$ themu abo thess sam tho komu poruczicz". It was essential because the information was honest that reaching the rallying point would take over two months. To dispel the Duke's anxiety about the possibility of deserting by volunteers after having taken the money, the rotamasters assured in Old Polish: "Bo myally bich pyenyądze oth V.X.M. wzyącz, a w czass $\mathrm{k}$ they posludze V.X.M. nye bicz, thedi bich syą bil volyal nye rodzycz na svyath" ${ }^{70}$ The information included in the treatise coincides with the result of the negotiations. For instance the Duke noted the higher pay negotiated by the soldiers (7 Polish ztotys) and described the rules of provisioning, which he was requested for.

The above analysis causes us to think that following the handover of the book to Sigismund Augustus in 1555 the Duke still collected military-related documentation. ${ }^{71}$ It is possible that already mentioned - the work by Schellenschmidt and the panegyric by Strubicz provided impetus for his work. The monumental book was intended to be aimed at European military elites. Regrettably, it was not completed because of a cerebral stroke that the Duke suffered on 22 September 1563 during the "Nut War". ${ }^{72}$ From that moment onwards, Albert of Hohenzollern's disability prevented him from fast-paced work but did not stop it completely. The writing was continued with the help of courtiers and secretaries but the aim of the work changed. Worsening paralysis, factional fights at the court and the minority status of the heir to the throne Albert Frederick prompted the Duke to prepare in 1565 Rejestr, being a part of his political testament,

${ }^{70}$ B. Pretwicz to Albert of Hohenzollern, Trembowla, 18 July 1555, in: Elementa ad Fontium Editiones, vol. 50, ed. C. Lanckorońska (Romae, 1980), pp. 80-83, 86; B. Pretwicz to Albert of Hohenzollern, Trembowla, 2 Aug. 1556, in: ibidem, pp. 91-95.

71 Sarnicki mentions about the handover of the books written by Jan Długosz to Albert of Hohenzollern: "Są ksiegi stare, które zowąm Banderiorum, jakie książęciu pruskiemu był posłał arcybiskup dzisiejszy [1577 - Jakub Uchański]. Jam je w książęcej bibliotece widział. Tam herbów jest wymalio[wa]nie własne", The Central Archives of Historical Records, the Potocki Family Public Archive, catalogue number 325, vol. 1, p. 300.

72 J. R. Fligge, Herzog Albrecht von Preußen und der Osiandrismus. 1522-1568 (Bonn, 1972), p. 490; Fischer, "Der Preußische Nußkrieg," p. 71. 
written at the time, including guidelines related to the future rules of his son. ${ }^{73}$

Extraordinarily important for the presented deliberations is chapter 24, the content of which I will describe in more detail. The author emphasised in the chapter that the ruler governs for the glory of God and the well-being of his subjects. To achieve these aims of internal policy the Duke has to use legal instruments above all. The monarch should always defend the state and if necessary personally participate in a military campaign, which requires a broad military knowledge both on desirable and inappropriate behaviour. Albert of Hohenzollern does not carry on at length over the issue in Rejestr informing his son that he may acquire all the necessary information through studying his treatise. Although he does not provide its title (which actually would not be of great help, since the titles of version $\mathrm{A}$ and $\mathrm{C}+\mathrm{D}$ are identical). He only remarks that the content is based on the experience of the ancients and his contemporaries. Albert of Hohenzollern encourages using the treatise as the basis for everyday learning of military profession, which may be utilized while organizing the army. In addition he recommends reading the work in situations when problems concerning the military arise, for instance what to avoid, how to gain advantage during the battle, what type of battle array should be formed, how to organise transportation of supplies (beverages and food) and what place to choose for a battle. ${ }^{74}$

73 See I. Kąkolewski, Nadużycia wtadzy i korupcja w Prusach Książęcych $w$ potowie XVI wieku. Narodziny państwa wczesnonowożytnego (Warszawa, 2000), passim (esp. chapt. III, IV and V).

${ }^{74}$ Cf.: "Von kriegssachen, wie die anzugreiffen etc., wie sie zu vermeiden etc. Solchs gehöret alles zum regiment und ist, sonderlich weil man frid hat, zu betrachten, zu ordnen und inn schang zu bringen, damit, wenn unfrid furfiele, das man gerust sei, dem unfriden zu wehren und den gotseligen friden wider anzuruchten etc. Was nu das kriegsregiment antrifft, sind so will schoner herrlicher buch furhanden in teutscher sprach, das es one not und uberflussig ist, etwas sonderlichs mehr darumb zu schreiben. Solchs wirdt aber durch lesen und betrachtung der alten und neuen historien [- - ] teglich vermehret und gleich als in ubung gebracht, thut auch vil darbei, wo ein herr bisweilen erfarne kriegslaut und der geschichten gelehrte leut neben andern bei sich hat, das er etwo eine geschicht, da ein fein kriegsstück innen gebraucht worden ist, ins mittel bringe und eines ieden iuridicium darvon höre. Er mag auch wol einen fall dichten, als wenns sich so oder so begebe, das einer mit solcher macht da oder do lege, der feinde aber dargegen so mechtig an dem oder jenem orte, in disem oder jenem vortheil, wie dem zu begegen?," Die Testamente Herzog Albrechts von Preussen aus den sechziger Jahren des 16. Jahrhunderts, ed. A. Bues, I. Kąkolewski (Wiesbaden, 1999), pp. 159-160. 
It should be stressed that the mentioned opinion of Albert of Hohenzollern is one of the most interesting sixteenth-century fragments concerning the practical application of military treatises. Until recently its identification did not pose any problem and according to existing knowledge the publisher of Rejestr was of the opinion that the Prussian Duke was referring to the work (A) written in $1555 .{ }^{75}$ However, the discovery of 2009 leads to a different conclusion because it is the treatise $\mathrm{C}+\mathrm{D}$ which seems to be a perfect military textbook for the minor heir to the throne. This is clearly shown by the attempt of comprehensive presentation of military issues, which was declared in the introduction to the treatise. It was stated that the work is a compendium of knowledge for commanders and officers.
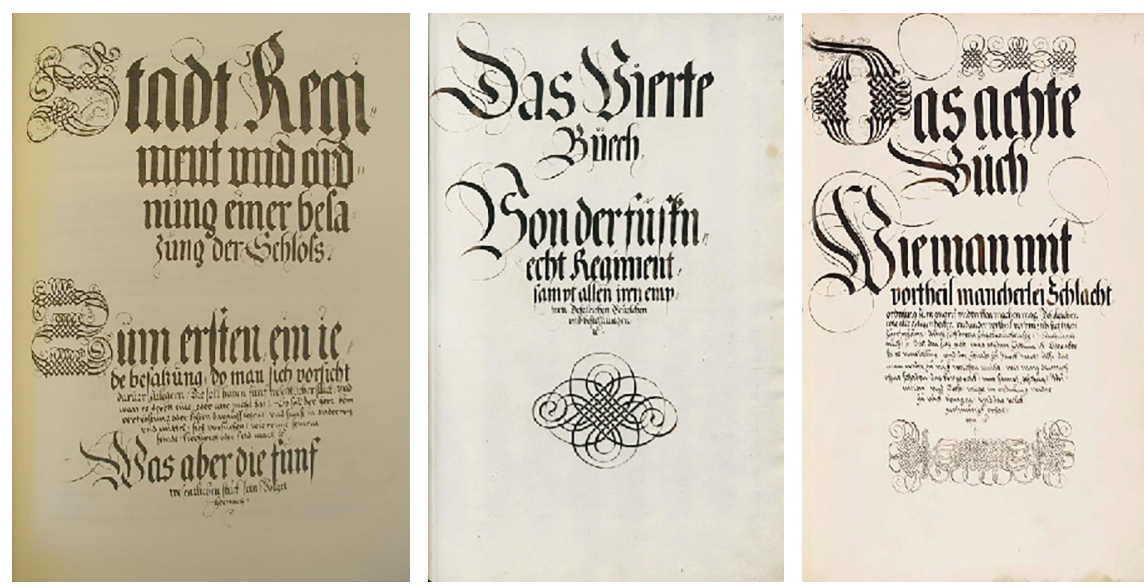

Fig. 5. The first pages of chapters (books) contained in treatises $A, C$ and $D^{76}$

It should be assumed that in 1565 there already existed the first volume of the work (C) and the basic elements of its second part (written before 22 September 1563), continuously written until 1568. In summary, Albert of Hohenzollern's work, identified in 2009 consists of two parts:

[A. Hohenzollern], Kriegs ordenung bin ich genant wer kriegt und ist in mir bekant, Der kan nach der Zeit und gestalt, all sein schlachtordnung machen balt, Auch brauchen manchen vortheil gut, dem feindt zustillen sein obermut contains Books I-VI. The manuscript was

75 Ibidem, p. 159, fn. 20.

76 Staatsbibliothek zu Berlin, Preußischer Kulturbesitz, Ms. boruss. fol. 441, fol. 1; ibidem, Ms. boruss. fol. 1254, p. 311; British Library, MS Harley 1413, fol. 59. 
purchased in 2009 by Ernst von Siemens Kunststiftung and handed over to Staatsbibliothek in Berlin. There it underwent archival processing and was prepared for access as a part of Preußischer Kulturbesitz (Ms. boruss. fol. 1254). ${ }^{77}$ The book made around 1565 has 381 folios and contains 60 one-page illustrations. The whole work consists of six thematically distinct books, where the first visibly divides into two separate issues. Pages 13-52 are devoted to the Turkish army and the necessity of fighting against the enemy with allied forces of Christian monarchs. The second part, up to the page 102 depicts the staff of the commander-in-chief, beginning from a colonel general, ending with heralds. Books II, III and IV (pp. 103-420) concern three military branches: cavalry, the artillery and infantry. The author primarily enumerates and characterizes necessary military officials and officers. The most extensively covered topics related to the artillery are types of cannons, tools, transportation and storage of gunpowder. ${ }^{78}$ The next book contains provisions of law (including oaths) binding in the army (pp. 421-648). Finally, the last part depicts the system of justice: appointment of courts, procedure rules and enforcement of court judgements;

[A. Hohenzollern], Kriegs ordenung bin ich genant wer kriegt und ist in mir bekant, Der kan nach der Zeit und gestalt, all sein schlachtordnung machen balt, Auch brauchen manchen vortheil gut, dem feindt zustillen sein obermut contains Books VII-X. The manuscript is stored at the British Library in the collection MS Harley under the number 1413. The manuscript dated to 1568 contains 225 folios, including 85 onepage and two-page unnumbered illustrations. ${ }^{79}$ Books VII and VIII are for the most part coinciding with the most valuable part of treatises A and B. Book VII (from fol. 1) concerns arraying units on the battlefield and in a camp and supplying them with food. Book VIII (from fol. 59) raises the issue of preparation of troops for battle and commanding during combat. Book IX (from fol. 136) concerning

77 Ovegaauw, "Die Kriegsordnung," pp. 62-63.

${ }^{78}$ It is possible that Sarnicki when writing Ksiegi hetmańskie made use of the work at least in reference to the artillery since he had access to the ducal library. He also mentions: "Jako w tem ma niemałą sławę Książę Je[go] M[ość] Pruskie nieboszczyk Olbrycht, pan mój, strony porządku strzelby i przewiezienia jej," The Central Archives of Historical Records, the Potocki Family Public Archive, catalogue number 325, vol. 1, p. 190.

79 Separate numbering is applied for 42 plans of battle arrays of the army. Cf. British Library, MS Harley 1413, fol. $90 \mathrm{f}$. 
the techniques of besieging and functioning of garrisons is similar to existing elaborations in terms of content. On the other hand, Book X (from fol. 181) about the art of war at sea should be regarded as completely novel against the background of Albert of Hohenzollern's achievements to date. ${ }^{80}$ From fol. 212 there are illustrations of military instruments, tools and devices.

Another surprise for the collectors' market occurred in 2014. On 8 July also at Sotheby's Art Auction House the Renaissance manuscript entitled Kriegsbericht unnd Memorial: Anno domini 1550 was put up for auction. ${ }^{81}$ Thanks to the support of Ernst von Siemens Kunststiftung also this work was purchased and handed over to the Berlin archive. ${ }^{82}$

Due to the fact that I could not personally examine the volume it only remains for me to replicate the findings of experts and those included in the description of an object at the auction supplemented with works of German archivists. ${ }^{83}$

The author did not reveal his name either on the title page or in the main text. Only the year of writing (1550) was clearly indicated. The authorship of the manuscript was ascribed to Albert of Hohenzollern on the basis of the heraldic shield (containing the eagle of the Hohenzollerns with Sigismund's monogram "S", similar to that on fig. 2) ( $^{84}$ and the likeness of the Duke, which appears at the beginning of the

${ }^{80}$ So far it was attributed to Sarnicki that he pioneered in the field of maritime military issues. He devoted Book IX $O$ zwyczaju morskiej bitwy to the subject. See $O$ zwyczaju morskiej bitwy, ed. and introduction J. Z. Lichański (Gdańsk, 1984), pp. 54-80.

81 Then 65 medieval and Renaissance documents were put up for auction, among them with number 43 there was a manuscript described as follows: "ALBRECHT OF BRANDENBURG, KRIEGSBERICHT UND MEMORIAL, ON THE COMPOSITION OF THE ARMY, IN GERMAN, ILLUMINATED MANUSCRIPT ON PAPER [NORTH-EAST GERMANY OR POLAND (PROBABLY KÖNIGSBERG), DATED 1550]". http://www.sothebys.com/en/auctions/ecatalogue/2014/medieval-renaissance-manuscripts-114240/lot.43.html (accessed: 11.08.2014).

82 The work was given the catalogue number: Staatsbibliothek zu Berlin, Preußischer Kulturbesitz, Ms. boruss., qu 574.

${ }^{83}$ See Handschriftenabteilung. Erwerbungen von 1997 bis 2016, pp. 155-156 (http:// staatsbibliothek-berlin.de/fileadmin/user_upload/zentrale_Seiten/handschriftenabteilung/abendlaendische_handschriften/pdf/Erwerbungen.pdf; accessed: 07.06.2017); http://www.sothebys.com/en/auctions/ecatalogue/2014/medievalrenaissance-manuscripts-114240/lot.43.html (accessed: 11.08.2014).

${ }^{84}$ See http://www.zeno.org/Kunstwerke/B/Beham,+Hans+Sebald\%3A+Wappen+des+Herzogs+Albrecht+von+Preu\%C3\%9Fen (accessed: 07.06.2017). 


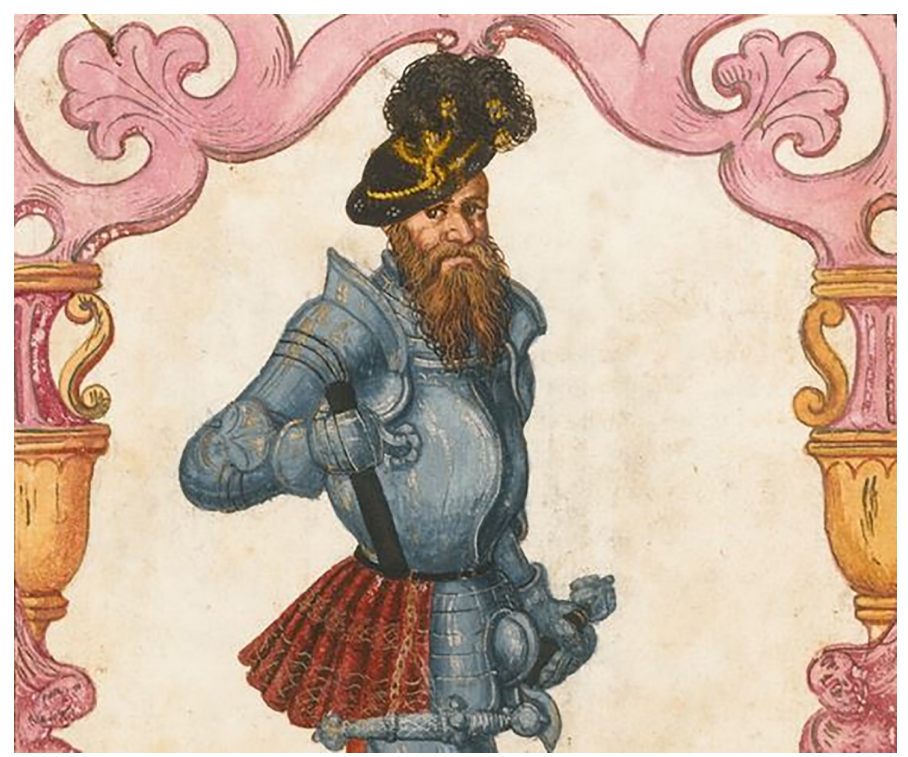

Fig. 6. Probable image of Albert of Hohenzollern in light of the manuscript E

manuscript (see fig. 6). It is a portrait of a man standing in a full suit of armour, decorated with vertical gilded strips (without a helmet). ${ }^{85}$ In the opinion of German archivists, the work in terms of its form, function and content coincides with the two other works of Albert of Hohenzollern stored in Berlin.

The work is relatively short - has 133 folios, of which 117 is filled with writing - and is limited to the description of military officials and officers. In the first place duties of Obirstenn Feldhauptmann were described (fol. 5ver.-33; 102 articles), then duties of: Obirsten Leutinandt (fol. 33ver.-36; 9 articles), FeldtMarschalck (fol. 36ver.43; 30 articles), Wach vnd Quartirmeister (fol. 44-48ver.; 20 articles), Quartirmeister (fol. 48ver.-50ver.; 10 articles), Reuterhauptleutenn (fol. 51-60; $26+3$ articles), Reuterhauptleutenn In gemeyn (fol. 60-60ver.; 3 articles), Obirsten (fol. 61-68; 31 articles). Subsequently, the duties of lower-ranking regimental officers and common

${ }^{85}$ As it was noticed by the team describing the manuscript Kreigsbericht und Memorial, the suit of armour worn by the probable Duke corresponds to that of the portrait of the Duke included in the work Kriegsordnung. See Staatsbibliothek zu Berlin, Preußischer Kulturbesitz, Ms. boruss., fol. 1254, p. 5. Cf. Z. Fuiński, "Garnitur zbroi," Studia do Dziejów Dawnego Uzbrojenia i Ubioru Wojskowego 9-10 (1988), pp. 127-128. 
soldiers were described. The whole work closes with articles of war and bestallungs (enrollment letters) for cavalry and infantry. ${ }^{86}$ The work contains also five full-page illustrations (fol. 2ver., 6, 33ver., 36ver., $61,78)$ depicting military officials.

It is worth to complement this assessment with information unknown to the sellers. It is doubtful that the book was within the territory of Great Britain in the eighteenth century as it was the case with the treatise $\mathrm{C}+\mathrm{D}$. The manuscript was found by the nineteenth-century researcher of the German military Hermann von Gansauge. In a treatise dated to 1833 he paid attention to existing in a handwritten form Kriegsbericht unnd Memorial: Anno domini 1550, and pointed out (without suggesting the same authorship) similarities to the work Kriegsordnung. ${ }^{87}$ Then, fragments of this work (again without the source of archival information) were published by Ernst Oswald Mentzel. ${ }^{88}$ The fragments presented there are identical with the content of the pages scanned for the needs of the auction. It is probable that the same manuscript is concerned. Thanks to the published fragments, we know that the content is far more interesting than it was presented in the description. The work describes for instance principles of using wagons in setting up and fortifying a military camp the author noticed for example differences between Western European (German, French, Italian and Spanish) and Eastern European (Turkish, Tatar, Muscovite, Lithuanian, Polish or Hungarian) art of war. ${ }^{89}$

The history of the manuscript may be determined to some degree on the basis of noteworthy research of Nadezda Shevchenko. The author while describing the Königsberg book collection of the wife of Albert Frederick of Hohenzollern - Marie Eleonore of JülichKleve-Berg paid some attention to the illuminated manuscript of 1550 entitled Kriegs Bericht Vnd Memorial. ${ }^{90}$ I note with amazement that the woman had a work concerning the art of war in her

${ }^{86}$ Handschriftenabteilung, p. 156.

${ }^{87}$ H. von Gansauge, "Beiträge zur Geschichte der Heeresverfassung im 16ten Jahrhundert," Zeitschrift für Kunst, Wissenschaft, und Geschichte des Krieges 27 (1833), pp. 269-270. Regrettably, the researcher did not impart the source information, however he used to work with archive materials in Berlin.

${ }^{88}$ E. O. Mentzel, Die Remontirung der Preußischen Armee in ihrer historischen Entwickelung und jetzigen Gestaltung (Berlin, 1845), pp. 18, 262-267.

${ }^{89}$ Ibidem, p. 263.

${ }^{90}$ N. Shevchenko, Eine historische Anthropologie des Buches. Bücher in der preussischen Herzogsfamilie zur Zeit der Reformation (Göttingen, 2007), pp. 259-260. 
collection. However, she explains that she selected sumptuous books to include in her library, or, what is particularly important, directly connected to the ruler of Prussia. There may have been for instance books dedicated to him as well as those containing the likeness of the Duke. Making the assumption that it was Albert of Hohenzollern's work adequately explains the said riddle. It is also worth mentioning the library catalogues of the Brandenburg-Prussian monarchs from Königsberg, produced in 1700 and 1720. In Catalogus Manuscriptorum Bibliothecae Electoralis Brandenburgicae Regiomontanae under the number 8 of the collection Silber-Schaff the book was recorded. It was noted that the volume was of quattro size, was illustrated and had an exceptionally beautifully gilded binding, at the time already considerably damaged..$^{91}$

The above mentioned information strengthens the hypothesis about Albert of Hohenzollern's authorship. It also indicates that the manuscript was stored at the Königsberg library at least until the 1730s. ${ }^{92}$ The next clue is a bookplate - a stamp containing a closed crown topped with a cross and the inscription "W.P.S.". Archivists from Staatsbibliothek in Berlin think, that it was the exlibris of "Wilhelm Prinz Solms-Braunfels"93 (born: Wilhelm Christian Karl of Solms-Braunfels 9 January 1759 - 20 March 1837). This means that the copy could not be transferred to the British Islands together with the two volumes of Kriegsordnung. During the auction enigmatic information was disclosed that the previous owner was a private art collector from North America, who had been the owner of the object for half a century.

The above mentioned facts reinforce the hypothesis about Albert of Hohenzollern's authorship. They also indicate that the manuscript was stored at the Königsberg library, then at the Berlin library. However, it is uncertain whether a figure depicted in the miniature in the

${ }^{91}$ B. Jähnig, "Katalog der Handschriften der landesherrlichen Bibliothek in Königsberg 1700/1720," in: Königsberger Buch-und Bibliotheksgeschichte, ed. A.E. Walter (Köln, 2004), p. 256.

92 On the website dedicated to the discussion about this manuscript, one of the participants of the discussion - Norbert Zsupanek - links the work to Reinhard Graf zu Solms. However, neither the content of Kriegsbericht und Memorial matches ideally with his works (naturally there is some general degree of similarity typical for the period), nor illustrations coincide with each other or are even similar. See https://archivalia.hypotheses.org/1228 (accessed: 07.06.2017).

${ }^{3}$ Handschriftenabteilung, p. 155. 
manuscript $\mathrm{E}$ is in fact the Prussian Duke (see fig. 6). ${ }^{94}$ The standing man in a full suit of armour (without a helmet) having red (brown) hair, beard and moustache, holding a baton in his right hand, when holding a sword hilt with his left hand admittedly resembles other images of the Prussian Duke as well as the likeness of Albert II Alcibiades (1522-1557). ${ }^{95}$ These are just speculations, of course, but possibly it was deemed as appropriate to portray intentionally the Margrave of Brandenburg-Kulmbach as "obirstern feldthauptman". ${ }^{96}$

To summarize the military scientific output of Albert of Hohenzollern, it can be concluded that he was the author of three separate works - manuscripts, significantly different from each other, of which one was translated into Polish. It transpires that in the mid-sixteenth century the Prussian Duke started systematic studies of military subject matter. It did not come about out of necessity but passion, the origin of which should be associated with the desire to gain recognition from his contemporaries. The discovered manuscripts indicate that he worked until the end of his life. Perhaps excessive meticulousness and his will to exhaust the subject prevented him from completing the work $(\mathrm{C}+\mathrm{D})$ and disseminating it.

It is worth considering why the Duke did not decide to publish in print at least one of his works? Due to his background he belonged to the group of authors, for which the costs of publishing did not constitute an obstacle. To answer this question it is worth paying attention to the specificity of the period. During the whole sixteenth century the number of handwritten military treatises is greater than that of printed ones, ${ }^{97}$ which should be linked, as Rainer Leng argues, not so much with the necessity of keeping the military knowledge

94 The Prussian Duke was described as a dark-brown-haired man with brown eyes. Cf. K. Górski, Zakon Krzyżacki a powstanie państwa pruskiego (Wrocław, 1977), p. 194. See Tondel, Srebrna Biblioteka, pp. 36, 79, 90, 109.

${ }^{5}$ Cf. O. Kneitz, Albrecht Alcibiades, Markgraf von Kulmbach: 1522-1557 (Kulmbach, 1982).

96 The close relations of the Prussian Duke with Albert II Alcibiades are well known. In the summer of 1545 he put forward a proposal of admitting Alcibiades to the Prussian fief. As a consequence, this proposal no longer existed after the moment of the pretender's death in 1557. Cf. Małłek, Prusy Ksiązęce, pp. 232 233, 262.

${ }^{97}$ Printed books written by Leonhart Fronsperger, despite a relatively high number of copies, were hand-copied at the time. See Riksarkivet, Skoklostersamlingen, E 8629, fol. 450; L. Fronsperger, Kriegs Ordnung und Regiment sampt derselbigen Befehl Statt und Empter zu Rossz und Fusz (Franckfurt am Mayn, 1564). 


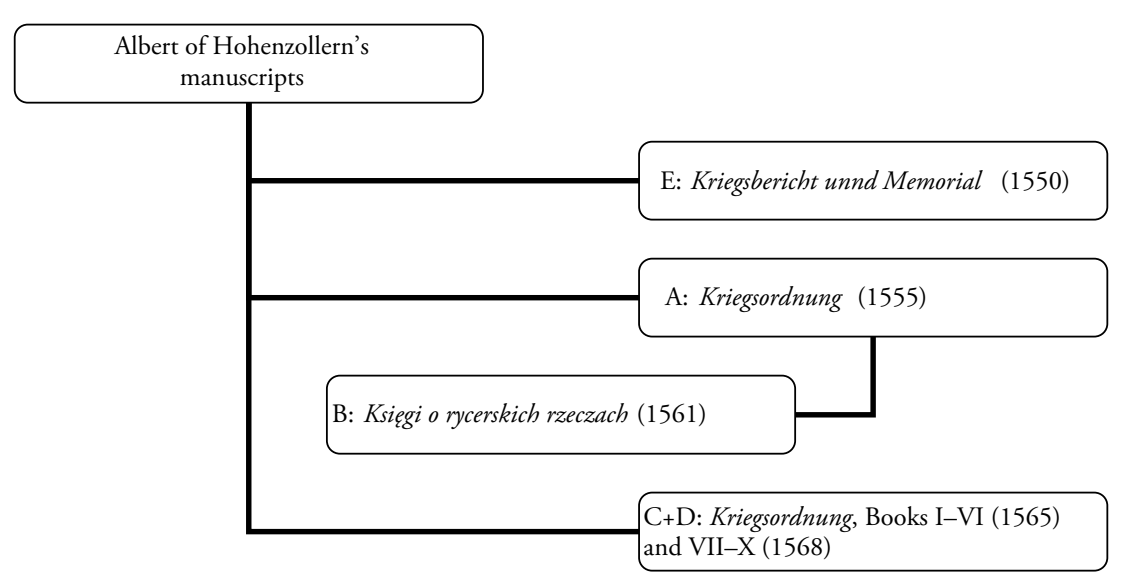

Fig. 7. The chronology of writing of Albert of Hohenzollern's works

secret but with the desire to maintain its exclusive and elite character. Even if particular titles were issued in print, the number of their copies was very low. Moreover, there were endeavours to illuminate manually individual copies. It gave the owner of such work a feeling of uniqueness, on the other side expensively issued (illustrated and sophistically bound) code raised the author's prestige. ${ }^{98}$ Paradoxically, the fact of producing a few or a dozen or so beautifully illuminated, handwritten copies instead of printing the work showed Albert of Hohenzollern's affluence.

The views presented above are perfectly illustrated by an occurrence, which took place during the war against Moscow in 1581: "Niemiec jeden, co jest w Farensbekowej rocie [oddziale Jerzego Farensbacha], oddał Królowi [Stefanowi Batoremu] księgi niemieckie wielkie, we złoto a zielony aksamit oprawne, drukowane po niemiecku o sztuce wojennej od Grafa von Solms, które napisał Graf Reinhard von Solms, ociec jego, który był marszałkiem wojennym u Karła V. ${ }^{99}$ Osobliwe księgi i wdzięczen ich Król barzo. Kupić ich

${ }^{98}$ Leng, Ars belli, vol. 1, pp. 390-398; Rogg, "Porzadek wojenny Albrechta," pp. $142-143$.

99 A book printed in Lich in the years 1559-1560 entitled Dises Buch und Kriegsbeschreibung ist vermelten und berichten einer guten ordentlichen Kriegsregierung nach alter teutschen Ordnung, Gebrauch und Herkomen mit anderen noch Büchern von aller Kriegsregierung und Rüstung, so zu dem Krieg gehört was delivered at the time. The content in comparison to Albert of Hohenzollern's works (A and $\mathrm{C}+\mathrm{D})$ does not distinguish itself with originality, providing more information about equipment useful for the artillery and building blockhouses. The Prussian 
nie dostanie nigdzie, bo ten Graf kazał je u siebie doma drukować i książętom, ludziom rycerskim tylko rozesłał; otóż syn jego, mając je jeszcze, posyła je Królowi”. In a later period a royal secretary Jan Piotrowski emphasises the importance of the book: "Cokolwiek jedno należy do wojny, wszytko w nich najdzie i dziś, gdy się z Farensbekiem rachowali o żołd, były im te księgi jako poradnik jeden, wedle których opisania i porządku odcięto mu żołdu niepotrzebnego niemało". ${ }^{100}$ The above quotation may indicate that only thirteen years after Albert of Hohenzollern's death his scientific achievements were falling into obscurity, superseded by other authors' works.

Karol Łopatecki, DSc, assistant professor at the Institute of History and Political Science at the University of Białystok. The author's interests concern military law and the theory of military revolution in the early modern period. $\mathrm{He}$ also conducts research on the cartography and regional history of Podlasie. E-mail: karollopatecki@gmail.com

\section{Trans. by Zbigniew Osypiuk}

First published as: "Twórczość wojskowa Albrechta Hohenzollerna. Uwagi nad trzema manuskryptami przypisanymi w latach 2009-2014 Albrechtowi Hohenzollernowi," Odrodzenie i Reformacja w Polsce 59 (2015), pp. 163-188 The publication of this English translation has received additional funding from the Ministry of Science and Higher Education of the Republic of Poland

Duke was focused on establishing military camps, using military wagon convoys, provided important tables presenting data on the surface area taken by troops set in battle array, in a camp and on a road. He described immeasurably more extensively the preparation of troops for battle.

100 J. Piotrowski, Dziennik wyprawy Stefana Batorego pod Psków, ed. A. Czuczyński (Kraków, 1894), pp. 68-69. 